\title{
Problem solving payment innovations in the digital economy
}

\author{
Olga M. Korobeynikova \\ Volgograd State Agrarian University \\ The Department of Economics \\ Department "Economic security and economy in \\ agribusiness" \\ Volgograd, Russia \\ korobeinikov77@yandex.ru
}

\author{
Dmitry A. Korobeynikov \\ Volgograd State Agrarian University \\ The Department of Economics \\ Department "Economic security and economy in \\ agribusiness" \\ Volgograd, Russia \\ korobeinikov77@yandex.ru
}

\author{
Larisa V. Popova \\ Volgograd State Agrarian University \\ The Department of Economics \\ Department "Economic security and economy in agribusiness" \\ Volgograd, Russia \\ lvpopova@bk.ru
}

\begin{abstract}
In order to ensure the national sovereignty of Russia and equalize the development of the regions, it is necessary to form a digital economy model and o organize its diffusion into all spheres of Russian society life. Assessment of the national payment system and its regional entities current state has shown that they are able to become the drivers for the introduction, transmission and dissemination of digital innovations. The article outlines the tasks of national payment system and regional subjects of the payment market digital innovation. To solve these tasks, a general algorithm for creating a digital financial ecosystem that unites markets and sectors of the economy on the basis of innovative platforms and technologies of payment systems and payment services is proposed. The proposed directions realize the main tasks of the digital economy for the national payment system and its regional elements, their implementation will promote the accessibility of payment services and the growth of financial and digital literacy through the development of a knowledge society based on innovative digital technologies.
\end{abstract}

Keywords - monetary circulation, payment systems, payment infrastructure, digital economy, regional economy, innovations

\section{INTRODUCTION}

The long-term socio-economic development of the Russian Federation forecast determines that the formation of a model of digital economy is required to preserve the national sovereignty and achieve global competitiveness on the basis of the non-primary development option [1]. The technological breakthrough ambitious objectives are to be solved systematically, but it should be noted that not all spheres are equally susceptible to digital innovations. In this situation, it seems rational to determine growth points [2] - the directions that can be the drivers of digital innovation in the scale of the national economy. One of such growth points is Russia payment system and its infrastructure in the regions. The importance of the regional component, in this article, is determined by the historically conditioned disbalance of the Russian regions development and the socio-economic potential of their equalizing growth. Introduction of digital innovations through the payment systems infrastructure will help to solve the problem of material and technical equipment and infrastructure support for the introduction of digital innovations and the formation of digital economy ecosystem in both public and private sectors, which is relevant for remote areas of the country.

The aims of the study are the argumentation of the digital economy tasks for the national payment system and its regional subjects as digital innovations conductors in other spheres of the economy, as well as the rationale for their practical implementation in the conditions for information society building. 


\section{MATERIALS AND MethodS (MODEL)}

A significant contribution to the development of the theory of money and money circulation, credit and financial systems, banks and banking was made by Abramova M.A., Markina E.V. [3], Baydukova N.V., Vasilyev S.A., Chepakov D.A. [4], Korobov Yu.I., Orlova A.N. [5], [6], Semenyuta O.G., Panchenko N.O. [7] and others.

The problems of payment systems theory and methodology, as well as, payment infrastructure were considered in the works by Russian and other specialists: Krivoruchko S.V., Lopatin V.A. [8], Obaeva A.S. [9], Travkina E.V., Kovalenko S.B. [10], Stiglitz J.E., Bhattacharya A. [11], Bech M.L., Preisig C. \& Soramaki K. [12] and so on.

Some aspects of Russian economy and the innovation of modern payment systems digitalization were developed by Kozenko Yu.A. [13], Epifanova O.N., Burkaltseva D.D., Tyulin A.S. [14] Tamarov P.A., Mikhailova M.A. [15] and others.

However, there are no unified approaches to the innovation of the payment sector due to the digital technologies in a separate region and the state introduction in the modern literature on the topic.

This research is based on general methodological scientific principles (the unity of theory and practice, objectivity, complexity, concrete-historical approach), as well as the systematic approach that assumes the formation of the current state of payment systems in the context of the diffusion of digital payment innovations into the economy of Russia and its regions integral picture.

\section{RESULTS AND DISCUSSION}

Modern scientific research and the application of Russian legislation on the national payment system [16] show that the latter has acquired qualities that characterize not only its own institutional readiness for embedding in the digital economy, but also the ability to transmit the impulses of digital innovations in the payment and settlement chains from organizational and technical and technological subjects of the national payment system to services users, creating conditions for the formation of digital environments of internal (economic payment services subjects-users) and external (between above mentioned economic entities). The national payment system is characterized by systemic openness and the desire to expand territorial and operational boundaries.

\section{A. National Payment System Dynamics.}

During the validity period of the Federal Law "On the National Payment System" in Russia, the number of payment systems increased by 1.75 times (or by 15 units), half of which was recognized as systemically significant (the payment system of the Bank of Russia and the non-bank credit organization "National Settlement Depository") or socially, providing the maximum coverage of economic entities. In connection with this, there is a decline in the number of banking system institutions, which are the operational basis of the national payment system, with 46451 units in 2012 to 34136 units as of 01.10 .2017 (or $36.08 \%$ ), which is connected with the policy of banking sector in Russia improving and banking services on a remote basis optimization [17, p. 247].

Data Bank of Russia for the Volgograd region indicate advancing (in comparison with the all-Russian dynamics) reduction in institutional provision of payment services associated with the peculiarities of the post-Soviet social and economic development of the region. The number of basic elements of the Volgograd region banking system institutions of the Bank of Russia, regional credit organizations, branches - is decreasing during the validity period of the law [16] from 772 units in 2012 to 548 units as of 01.10 .2017 (or $40.88 \%$ ). As a result, the region has a lower level of payment services than the average Russian data - the number of bank institutions per 1 million Volgograd users by 2018 was 214 units against 245 units in general, across Russia [18]. At the same time, the volume of the banking system operations of Russia and Volgograd region in quantitative and cost terms are steadily growing. The presented dynamics indirectly confirms the world trend of quantity to quality transition [19]: credit institutions, on the one hand, pursuing a client-oriented strategy, on the other hand, optimizing their own costs, replacing the multi-channel contact with customers (through offices and departments, call centers and other contacts forms) by omnichannel interaction through mobile devices and the Internet bank.

All four Volgograd credit organizations - Joint Stock Commercial Bank "KOR", commercial bank "Mikhailovskiy Promzhilstroybank", PJSC Commercial Bank "Russky Yuzhny Bank" ("Russian South Bank"), PJSC "Nokssbank", are the participants of the national payment system and the partners of its infrastructure elements. Within the national payment system, these banks issue and acquire bank cards, providing retail customers with access not only to national, but also to cross-border payment products and services. Actively participating in the full-fledged digital environment formation, regional banks can become carriers of digital innovations in the region's economy both on a remote basis and through traditional territorially dispersed offices.

\section{B. Payment System Elements Digital Economy Tasks Setting}

The current state of the national payment system and payment infrastructure in the Volgograd region shows their ability to implement the digital economy tasks, which allows considering the payment sector as one of the points of introduction, transmission and dissemination of digital innovations (see Table I). 
TABLE I.

DIGITAL

ECONOMIC TASKS TO BE ACCOMPLISHED BY THE NATIONAL PAYMENT SYSTEM AND ITS REGIONAL ELEMENTS ${ }^{\mathrm{A}}$

\begin{tabular}{|c|c|c|}
\hline \multirow{2}{*}{$\begin{array}{l}\text { Digital } \\
\text { Economy } \\
\text { Tasks }\end{array}$} & \multicolumn{2}{|c|}{ Digital Economy Tasks Setting } \\
\hline & $\begin{array}{c}\text { For National Payment System } \\
\text { (basic directions) }\end{array}$ & $\begin{array}{c}\text { For Refional } \\
\text { Elements (private } \\
\text { events) }\end{array}$ \\
\hline $\begin{array}{l}\text { Digital } \\
\text { Economy } \\
\text { Ecosystem } \\
\text { Creation }\end{array}$ & $\begin{array}{l}\text { - creation of an ecosystem of the } \\
\text { payment market, built into the } \\
\text { ecosystem of the digital economy; } \\
\text { - improvement of institutional, } \\
\text { infrastructural, technological bases } \\
\text { of functioning of the national } \\
\text { payment system; } \\
\text { - creation of conditions for the entry } \\
\text { of regional entities into the } \\
\text { ecosystem of the payment market }\end{array}$ & $\begin{array}{l}\text { - modernization of } \\
\text { the payment market } \\
\text { in the region on the } \\
\text { basis of digital } \\
\text { platforms and } \\
\text { technologies; } \\
\text { - ensuring conditions } \\
\text { for diffusion of } \\
\text { digital innovations in } \\
\text { the region }\end{array}$ \\
\hline $\begin{array}{l}\text { Digital data } \\
\text { usage as a key } \\
\text { production } \\
\text { factor }\end{array}$ & $\begin{array}{l}\text { - standardization of digital services } \\
\text { in the segments of the payment } \\
\text { market; } \\
\text { - adaptation of Russian } \\
\text { cryptographic and other methods of } \\
\text { protecting digital data to payment } \\
\text { market operations; } \\
\text { - implementation of digital data } \\
\text { platforms }\end{array}$ & 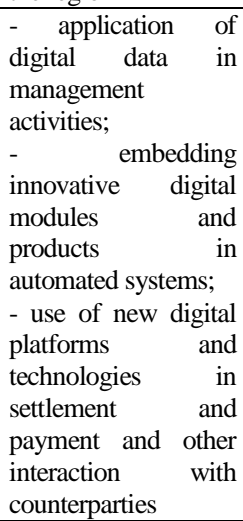 \\
\hline $\begin{array}{l}\text { nsuring } \\
\text { internal and } \\
\text { cross-border } \\
\text { interaction } \\
\text { between } \\
\text { business, the } \\
\text { scientific and } \\
\text { educational } \\
\text { community, } \\
\text { the state and } \\
\text { citizens }\end{array}$ & $\begin{array}{l}\text { - specialized scientific and } \\
\text { educational activities support; } \\
\text { - conducting information and } \\
\text { consulting activities to promote } \\
\text { digital interaction with business } \\
\text { structures and citizens; } \\
\text { - development of cross-cutting } \\
\text { interdisciplinary research; } \\
\text { - creation of a methodical basis for } \\
\text { the introduction of digital } \\
\text { competences }\end{array}$ & $\begin{array}{l}\text { - adaptation of the } \\
\text { system of contractual } \\
\text { contractual relations } \\
\text { to mechanisms for } \\
\text { the use of digital } \\
\text { innovative products } \\
\text { and services; } \\
\text { - local development } \\
\text { of digital } \\
\text { competences }\end{array}$ \\
\hline $\begin{array}{l}\text { Institutional } \\
\text { and } \\
\text { infrastructural } \\
\text { conditions for } \\
\text { subjects of } \\
\text { high-tech } \\
\text { business and } \\
\text { high-tech } \\
\text { markets } \\
\text { creation }\end{array}$ & $\begin{array}{l}\text { - assistance in the creation of digital } \\
\text { economy institutions; } \\
\text { - protectionism of digital interaction } \\
\text { of subjects of the national payment } \\
\text { system; } \\
\text { - development of communication } \\
\text { networks and information } \\
\text { processing centers of Russian } \\
\text { origin; } \\
\text { - support for industry standards of } \\
\text { the digital economy in the personnel } \\
\text { sphere }\end{array}$ & $\begin{array}{l}\text { - industry standards } \\
\text { application of the } \\
\text { digital economy in } \\
\text { the personnel sphere; } \\
-\quad \text { use of digital } \\
\text { networks of Russian } \\
\text { origin }\end{array}$ \\
\hline $\begin{array}{l}\text { Global } \\
\text { competitivenes } \\
\mathrm{s} \text { of industries } \\
\text { and the } \\
\text { economy } \\
\text { increasing }\end{array}$ & $\begin{array}{l}\text { - promotion of high-tech payment } \\
\text { platforms and services; } \\
\text { - information security }\end{array}$ & $\begin{array}{l}\text { - provision of high- } \\
\text { technology payment } \\
\text { services; } \\
-\quad \text { ensuring } \\
\text { information security. }\end{array}$ \\
\hline
\end{tabular}

a. source: created by the authors

\section{Digital Economy Tasks Solving Mechanisms}

Within the framework of Russia Long-Term Social and Economic Development [20] according to a forced scenario, the solution of the tasks set in the table is associated with the development of the payment market new segments based on innovative platforms and technologies (Fig.1).

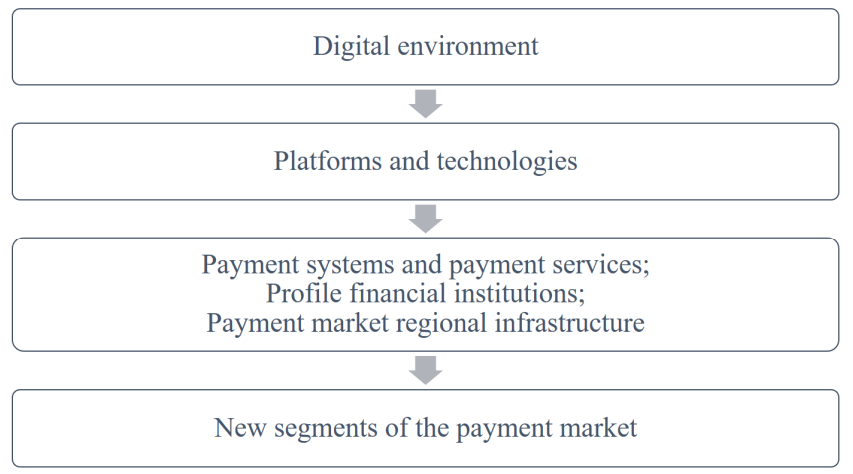

Fig. 1. General scheme of the digital financial ecosystem and new segments of the payment market formation.

The digital financial ecosystem is formed by the payment market created by the offer (from the payment systems offering services in the form of payment services) and demand (from consumers of payment services) interaction.

In solving the problems of the digital economy, from the side of offering payment services, in addition to payment systems and the payment services they represent, profile financial institutions [21], as well as the regional infrastructure of the payment market, are involved. Institutional elements that form the digital environment include: a megaregulator (the Bank of Russia), development institutions, banking organizations and their institutions and associations, nonbanking financial institutions and their communities, specialized public organizations, financial and IT communications institutions. The main task of the payment market institutions is achievement of the country's national payment system sovereignty while ensuring its security and efficiency. The payment market infrastructure includes a regional system of education and retraining of personnel in mastering the competences of the digital economy, both specialists and payment systems users, research infrastructure, industry standards that take into account the digital economy competencies, intellectual property. The common task of the payment market institutions to promote digital technologies is the formation of a common digital environment, which, in turn, is associated with the solution of particular tasks to achieve the sovereignty of the national payment system and equalize regional development.

The demand for digital payment products is formed by consumers based on financial needs and digital and financial literacy. Along with the traditional demand for payment system services, the digitalization of the economy will stimulate the demand for hybrid products of payment systems and other (including non-financial) sectors of the economy spheres of activity). Such hybrid products can give rise to a payment services and services in the priority areas for the state 
symbiosis. Diffusion of financial digital innovations in payment systems to other spheres of the economy will occur on the basis of platforms and technologies development on which the competences for the development of the payment and related markets themselves are formed: robotization and artificial intelligence, distributed registries (blockchain), cloud computing, biometrics, which form the technological component of the new digital environment. Innovative platforms and technologies, in turn, form new (or updated) segments of the market: the financial market (FinNet) and in its structure of the payment market (PayNet). Such promising segments of the payment market are: cloud and mobile services, operations with large data, open interfaces, as well as the Internet of things.

\section{CONCLUSION}

The presented directions carry out the main tasks of the digital economy for the national payment system and its elements: the improvement of payment networks that ensure the communication needs of the economy for payment and settlement services to state and municipal structures, business entities and the population, taking into account the technical requirements imposed by digital technologies; translating processing exclusively into sovereign Russian data centers, providing sustainable, secure and cost-effective payment services throughout the country; introduction of innovative technologies and digital platforms).

The final results of the tasks set for the national payment system and its elements solution in the diffusion of digital innovations in the implementation of the "Digital Economy of the Russian Federation" [22] program will create conditions for improving the welfare of the Russian population, security and quality of life, accessibility of digital financial services, digital literacy through the development of a knowledge society based on innovative digital technologies.

\section{Acknowledgment}

The study was carried out with the financial support of the RFBR and the Administration of the Volgograd Region under the project "Payment Infrastructure Modernization and the Development of Innovative Payment Services in the Region (basing on the example of the Volgograd Region)" No. 17-1234037.

\section{References}

[1] Diana Dmitrievna Burkaltseva, Olga Sergeevna Sivash, Oleg Valerievich Boychenko, Lyubov Vasilievna Savchenko, Tatyana Nikolaevna Bugaeva, Snezhana Anatolyevna Zotova. (2017). Realization of Investment Processes in the Agricultural Sector of the Digital Economy. European Research Studies Journal, Volume XX, Issue 4B, pp. 366-379

[2] Regional economy of the Crimea: points of growth [Regional'naya ekonomika Kryma: tochki rosta], [L. M. Borsch et al.], Simferopol: LLC "Antikva", 2017, 284 p.

[3] Monetary and financial system [Denezhno-kreditnaya i finansovaya sistema]/ the collective of authors ; under the editorship of M. A. Abramova, E. V. Markina. - M. : KNORUS, 2016, 446 p.
[4] Baydukova N.V., Vasilyev S.A., Chepakov D.A. The banking system and the megaregulators in the financial market: foreign experience and domestic practice [Bankovskie sistemy i megaregulyatory na finansovom rynke: inostrannyi opyt i otechestvennaya praktika] Bulletin of Saint-Petersburg state University [Izvestiya Sankt-Peterburgskogo gosudarstvennogo universiteta], 2016, no. 1, pp. 17-26

[5] Korobov Yu.I. The development of the banking system: modernisation or transformation? [Razvitie bankovskoi sistemy: modernizatsiya ili transformatsiya?] Science and society [Nauka i obshchestvo] 2015, no. 3(22), pp. 39-41

[6] Korobov Yu.I., Orlova A.N. Paradoxes of the Russian banking system [Paradoksy bankovskoi sistemy Rossii] Finance, money, investment [Finansy, den'gi, investitsii], 2010, no. 3, pp. 7-11

[7] Semenyuta O.G., Panchenko N.O. The banking sector of Russia - the basis of modernization of the domestic economy [Bankovskii sektor Rossii - osnova modernizatsii otechestvennoi ekonomiki] Finance and credit [Finansy i kredit], 2013, no. 41 (569), pp. 2-7

[8] Krivoruchko S.V., Lopatin V.A. Banks as the subjects of the national payment system: contemporary issues [Banki kak sub"ekty natsional'noi platezhnoi sistemy: sovremennye problemy] Financial journal [Finansovyi zhurnal], 2016, no. 2, p. 113

[9] Obaeva A.S. National payment system: infrastructure, innovation, prospects of development [Natsional'naya platezhnaya sistema: infrastruktura, innovatsii, perspektivy razvitiya] Money and credit [Dengi i kredit], 2010, no. 5, pp. 34-41

[10] Travkina E.V., Kovalenko S.B. Supervision of Bank of Russia behind activity of commercial banks [Nadzor Banka Rossii za deyatel'nost'yu kommercheskikh bankov] Traditional and innovative science: history, modern condition, prospects. Collection of articles of International scientific-practical conference.- Ufa: "Aeterna", 2016, pp. 139-141

[11] J.E. Stiglitz, A. Bhattacharya Underpinnings for Stable and Equitable Global Financial System. N.-Y.: World Bank, 1999

[12] M.L. Bech, C. Preisig and K. Soramaki Global Trends in Large-Value Payment. FRBNY Economic Policy Peview. September 2008

[13] Kozenko Yu.A. Prospects for the use of digital payment systems backed by gold [Perspektivy ispol'zovaniya tsifrovykh platezhnykh sistem, obespechennykh zolotom]. Business. Education. Right. Bulletin of the Volgograd business Institute [Biznes. Obrazovanie. Pravo. Vestnik Volgogradskogo instituta biznesa], 2013, no. 4, pp. 184-188.

[14] Epifanova O.N., Burkaltseva D.D., Tyulin A.S Use of blockchain technology in the public sector [Ispol'zovanie tekhnologii blokchein $\mathrm{v}$ gosudarstvennom sektore] Electronic currency in the light of modern legal and economic challenges proceedings of the International scientific-practical conference.- Simferopol, 2016, pp. 88-97

[15] Tamarov P.A., Mikhailova M.A. Development of retail payment services: payment services offering payment system [Razvitie roznichnykh platezhnykh uslug: ot platezhnykh servisov $\mathrm{k}$ uslugam platezhnoi sistemy] Money and credit [Den'gi i kredit] 2012, no. 9, pp. 31-39

[16] Federal law of the Russian Federation of 27.06.2011 № 161-FZ "On national payment system" [Federal'nyi zakon Rossiiskoi Federatsii ot 27.06.2011 № 161-FZ «O natsional'noi platezhnoi sisteme»] Collected legislation of the Russian Federation [Sobranie zakonodatel'stva Rossiiskoi Federatsii], 2011, no. 27

[17] Korobeynikova O.M., Korobeynikov D.A. The problems of the transmission of monetary and credit resources in the context of monetary policy [Problemy transmissii denezhnykh i kreditnykh resursov $\mathrm{v}$ kontekste provedeniya denezhno-kreditnoi politiki] Proceedings of the lower Volga agrodiversity complex: science and higher professional education [Izvestiya Nizhnevolzhskogo agrouniversitetskogo kompleksa: nauka i vysshee professional'noe obrazovanie], 2015, no. 2(38), pp. 246-251

[18] Official website of the Bank of Russia. Statistics. Statistics of the national payment system. [Electronic resource].- Mode of access: http://www.cbr.ru/ statistics/?prtld= psrf (accessed 11.01.2018)

[19] O.M. Korobeynikova, D.A. Korobeynikov, L.V. Popova, O.V. Savina, R.S. Kamilova The current state of the payment infrastructure and development of payment systems in Russia and the Volgograd region// Espacios, Volume 38, Issue 62, 2017, URL: 
http://www.revistaespacios.com/a17v38n62/17386211.html (accessed 29.12.2017)

[20] Forecast long-term socio-economic development of the Russian Federation for the period up to 2030 (developed by the Ministry of economic development) [Electronic resource] URL: http:// base.garant.ru/70309010/\#friends (accessed 11.12.2017)

[21] Kopytin V.Yu. New trends in the development of retail payment services [Novye tendentsii $\mathrm{v}$ razvitii roznichnykh platezhnykh uslug]
Calculations and operational work in commercial Bank [Raschety i operatsionnaya rabota $v$ kommercheskom banke], 2010, no. 1, pp. 28-34

[22] "the Digital economy of the Russian Federation" the Decree of the RF Government of July 28, 2017 No. 1632-p [Electronic resource] URL: http://static.government.ru/media/files/9gFM4FHj4PsB79I5v7yLVuPgu 4bvR7M0.pdf (accessed 11.01.2018) 